\title{
Ocorrência de queima foliar em árvores de Santa Bárbara (Melia azedarach) causado por Cercospora meliae
}

\author{
Daniel Dias Rosa ${ }^{1,2^{*}}$; Paola Jennifer Bocardo ${ }^{1}$; Helenize Gabriela de Souza ${ }^{1,3}$;Edson Luiz Furtado ${ }^{1,2}$
}

${ }^{1}$ Universidade Estadual Paulista, Faculdade de Ciências Agronômicas, Departamento de Produção Vegetal - Setor de Defesa Fitossanitária, CP 237, CEP: 18603-970 Botucatu, SP. ${ }^{2}$ Bolsista do CNPq. ${ }^{3}$ Bolsista da FAPESP

Autor para correspondência: Daniel D. Rosa ddrosa@gmail.com

Data de chegada: 10/07/2007. Aceito para publicação em: 27/05/2008

Conhecida popularmente como árvore de Santa Bárbara ou cinamomo, a Melia azedarach L. é uma espécie arbórea de até 20 metros de altura que produz uma madeira de cor esbranquiçada a avermelhada, com veios castanhos. Pertencente a família Meliaceae, é originaria do sudeste asiático e apresenta-se esporadicamente nas Américas, no Mediterrâneo e na África. Atualmente, é muito utilizada para arborização urbana, pois apresenta flores aromáticas e tem folhagem caduca. Popularmente, é uma planta que apresenta uso inseticida, sendo que o extrato de suas folhas é utilizado na forma de pulverização sobre insetos pragas (Brunherotto \& Vendramim, Neotropical Entomology 30:455. 2001).

No mês de março de 2007, observaram-se plantas de $M$. azedarach com manchas foliares irregulares de coloração parda, regiões necróticas e encarquilhamento (Figura 1A). Folhas foram coletadas e enviadas para a Clinica Fitopatológica, do Departamento de Produção Vegetal - Setor de Defesa Fitossanitária, da Faculdade de Ciências Agronômicas - FCA/UNESP de Botucatu para análise.

As folhas coletadas foram submetidas ao exame de diagnose em microscópio estereoscópico óptico e foi observado a formação de pontuações enegrecidas nas regiões necróticas. Na face abaxial das lesões, observou-se a presença de intensa esporulação enegrecida de um fungo (Figura 1B), cuja morfologia correspondia ao gênero Cercospora (Crous \& Braun, Mycosphaerella e seus anamorfos. CBS. The Netherlands.2003).

$\mathrm{Na}$ análise em microscopia otica, observou-se que os conidióforos são agrupados em fascículos, de 3 a 15 conidióforos, hialinos, simpodiais, mostrando cicatrizes conidiais truncadas e espessadas (Figura 1D), medindo $22 \pm 4 \mu \mathrm{m}$ X 5,2 $\pm 1,2 \mu \mathrm{m}$, já os conídios apresentam cicatrizes truncadas, escuras e espessadas, medindo $90,8 \pm 14 \mu \mathrm{m}$ X 3,7 $\pm 0,8 \mu \mathrm{m}$, com 3 a 5 septos (Figura 1C), baseado nessas características identificou-se o fungo como sendo Cercospora meliae Ellis \& Everh.(1887)(Ellis \& Everhart, Journal of Micology 3:13. 1887) (sin. Cercospora leucosticta Ellis \& Everh. 1888 ) (Note: Chupp (1953) pg. 385 (Chupp, C. 1953. Monograph of the fungus genus Cercospora. Ithaca, New York, 667 pages. (786)).

Para confirmação da patogenicidade efetuou-se a inoculação do patógeno, utilizando-se o inoculo obtido das folhas doentes, sendo então pulverizadas sobre as folhas de plantas sadias, numa concentração de $2,0 \times 10^{4}$ conídios $/ \mathrm{mL}$, e essas mantidas em câmara úmida por 24 horas, em temperatura ambiente e depois acondicionadas em estufa a $22^{\circ} \mathrm{C}$, com fotoperíodo de 12 hora de luz. Dez dias após a inoculação, observaram-se lesões necróticas somente nas folhas inoculadas, não sendo observados nas folhas que serviram de testemunhas. A partir das lesões resultantes, realizou-se o re-isolamento do patógeno, obtendo-se a cultura pura

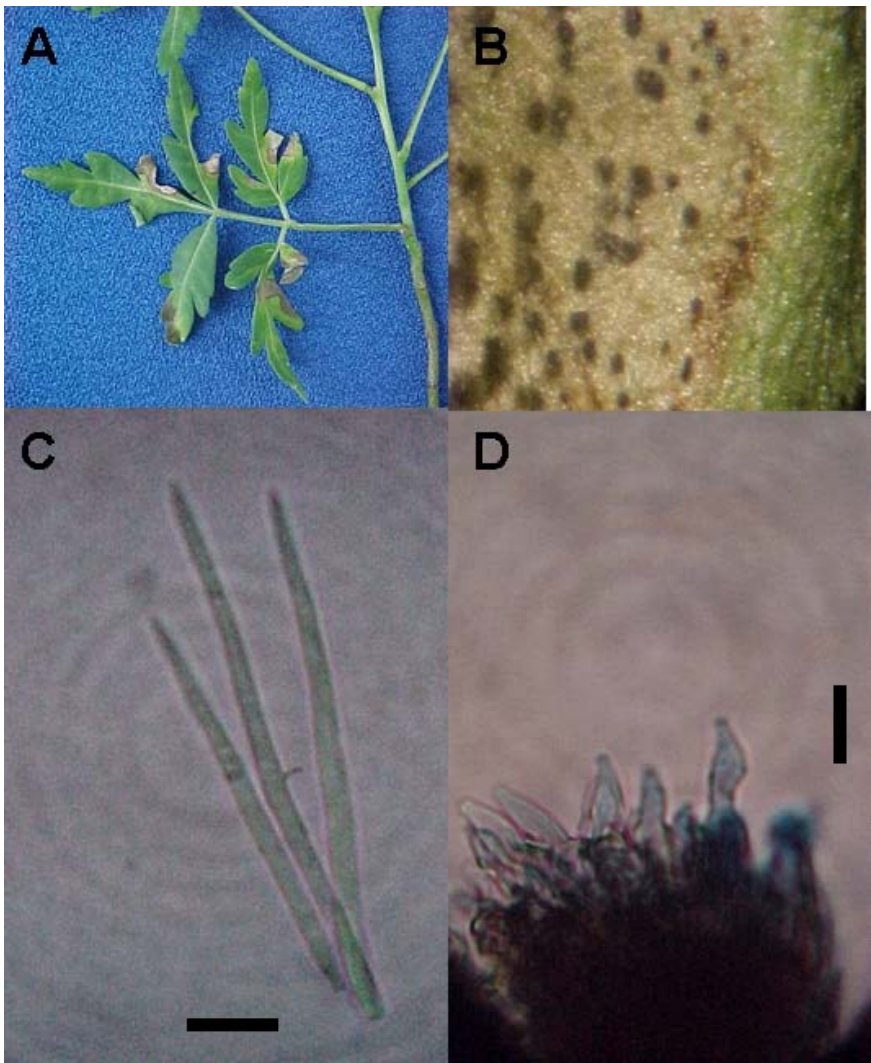

Figura 1 - Sintomas da cercosporiose em Santa Bárbara (Melia azedarach): A. Lesões foliares, irregulares e de coloração parda-escura; B. Lesão ampliada (50X) apresentando pontuações enegrecidas; C. Conídios de Cercospora meliae; D. Conidióforos hialino e simpodiais, mostrando cicatrizes conidiais truncadas e espessadas. Barras de $10 \mathrm{ì} \mathrm{m}$.

do fungo, confirmando-se assim a etiologia da doença. Atualmente, são conhecidas espécies de Cercospora em M. azedarach, são elas: Cercospora meliicola, na Índia e Argentina; Cercospora apii nos Estados Unidos, Cercospora subsessilis, na Argentina, China, Cuba, Republica Dominicana, Índia, Filipinas, Porto Rico, Sudão, Taiwan, Venezuela, Ilhas Virgens e nos Estados Unidos, Cercospora meliae, na África do Sul, Índia, China, Estados Unidos, Paquistão, Paraguai e Taiwan e Cercospora domingensis na Republica Dominicana, sendo este o primeiro relato de Cercospora meliae em Melia azedarach, no Brasil. Folhas doentes foram herborizadas e depositadas no herbário do Laboratório de Patologia Florestal, da Faculdade de Ciências Agronômicas - FCA/UNESP em Botucatu (HPF-350). 